\title{
Az alvászavar és a metabolikus szindróma kapcsolata
}

\author{
Rafael Beatrix ${ }^{1,2}$, Perényi Dóra Roberta², Kósa István ${ }^{1}$ \\ 'SZTE ÁOK, Orvosi Rehabilitációs és Fizikális Medicina Tanszék, Szeged \\ ${ }^{2}$ SZTE BTK, Pszichológiai Intézet, Szeged
}

Levelezési cím: rafaelbeatrix@gmail.com

A publikáció célja az alvászavar és a metabolikus szindróma kapcsolatának elemzése.

A metabolikus szindrómában (MS) szenvedők száma évről-évre nő. Mivel ismert rizikótényezője a szív- és érrendszeri megbetegedéseknek és a 2-es típusú diabétesznek, ezért fontos azon tényezők feltárása, amelyek változtatásával a betegség megelőzhető, vagy a szindrómában szenvedők életszínvonala javítható. A pszichoszociális kockázati tényezők közül az alvászavarra fókuszálunk és vizsgáljuk kapcsolatát a metabolikus szindrómával.

Eddigi kutatások szignifikáns összefüggést találtak a rövid alvási idő, a rossz alvásminőség és a metabolikus szindróma jellemző tüneteinek megjelenése között. A hosszú alvásidő tekintetében nem ilyen egyértelmüek a kutatási eredmények. Az alvászavar és a metabolikus szindróma oki kapcsolatának pontosabb vizsgálatához további longitudinális kutatásokra van szükség, ahol az alvás mérése objektív eszközökkel történik, valamint figyelembe kell venni a résztvevők korát, nemét, lakóhelyét és szocioökonómiai státuszát.

Kulcsszavak: metabolikus szindróma, alvászavar, cirkadián ritmus, 2-es típusú diabétesz

\section{Relationship between sleep disorders and metabolic syndrome}

The aim of this study was to analyse the relationship between sleep disorders and metabolic syndrome. The number of people with metabolic syndrome (MS) is increasing year after year. It is known that metabolic syndrome is a risk factor for cardiovascular disease and type 2 diabetes, so it is important to identify the risk factors for MS and improve the quality of life who is suffering from this syndrome. Among the psychosocial risk factors we focused on sleep disorders and investigated their relationship with metabolic syndrome.

Several studies have confirmed that short sleeping time and poor sleep quality are associated with higher risk for metabolic syndrome. The relationship between long sleeping time and MS is less clear. Further longitudinal studies are needed to investigate the relationship between sleep disorders and metabolic syndrome, where sleeping is measured by objective means, and participants' age, gender, place of residence and socioeconomic status are taken into account. Keywords: metabolic syndrome, sleep disorders, circadian rhythm, type 2 diabetes

\section{Bevezetés}

A metabolikus szindróma (MS) civilizációs népbetegségnek számít. Egységes definíciója egyelőre nem született, mert a különböző egészségügyi szervezetek eltérő kritériumokat helyeztek előtérbe a betegség di- agnosztizálásához. Ez megnehezíti a kutatások összehasonlíthatóságát és reprodukálhatóságát $(1,2,3,4,5)$. Jellemző tünetei a magas vérnyomás, magas vércukorés koleszterinszint, has tájéki elhízás, zsíranyagcsere-zavar (dyslipidaemia), inzulinrezisztencia (IR), és az emiatt kialakuló hyperinsulinaemia $(\mathrm{HI})(2,6)$. 
Az életkort is figyelembe vevő és korrigáló statisztikák szerint világszerte körülbelül $35-40 \%$ az érintett, és számuk évről-évre nő. Idősebb korban még gyakoribb az előfordulás. Nemek tekintetében pedig elmondható, hogy átlagosan több nő az érintett, mint férfi (1).

A betegségben szenvedők száma évről-évre nő, ami az adott személyek életminőségének romlása mellett globális közegészségügyi problémát is hordoz, mert jelentős gazdasági terhet jelent mind a társadalom mind az egyén számára. Így fontos azonosítani azokat a változtatható pszichológiai tényezőket is, amelyek a szindróma kialakulásában szerepet játszhatnak $(2,7)$.

Cikkünkben a pszichoszociális kockázati tényezők közül a szintén népbetegségnek számító alvászavarokra szeretnénk fókuszálni. A legfrissebb szakirodalom segítségével ismertetjük a tudomány mai állását a témában, valamint a feltételezhető mechanizmusokat, amelyek hozzájárulhatnak a metabolikus szindróma kialakulásához az alvászavarban szenvedőknél.

\section{Az alvásról és alvászavarokról}

Az alvászavar szintén népbetegségnek számít, amely mögött számos különféle ok húzódhat meg (8). Egyaránt megjelenhet meglévő betegség kísérőjeként, mint például depresszió és szorongásos zavarok tüneteként, és önálló betegségként is, mint pl. inszomnia, alvási apnoe szindróma, narkolepszia vagy nyugtalan láb szindróma stb. $(7,8)$.

$A z$ alvás az életben maradáshoz nélkülözhetetlen szükséglet a szervezet számára $(4,9)$. Ez a biológiai folyamat kritikus szerepet játszik az agy, az anyagcsere, az étvágyszabályozás, az immun-, hormon- és kardiovaszkuláris rendszerek müködésében. Az optimális alvásmennyiség egyénenként változó. Általánosságban véve azonban elmondható, hogy körülbelül 7-9 óra szükséges a szervezet optimális müködéséhez (4). Annak ellenére, hogy az emberek életük egyharmadát töltik alvással, a kielégítő alvás egyáltalán nem adatik mindenkinek (10). Az Egyesült Államokban kb. 70 millió ember, Európában pedig megközelítőleg 45 millió ember szenved krónikus alvászavarban, amely kihat a személy egészségére és életminőségére $(4,5)$. Alvászavarról akkor beszélünk, ha az alvás időtartama, időzítése, minősége, és rendszeressége eltér az optimálistól. Életvitel, környezeti faktorok, pszichoszociális tényezők és gyógyszerek is okozhatnak alvásproblémákat (4).

Ez az alapvető biológiai folyamat gyors szemmozgással járó (rapid eye movement; REM) és gyors szemmozgás nélküli (non-rapid eye movement; NREM) ciklusok váltakozásából áll. Utóbbi további három szakaszra osztható fel. A gyors szemmozgás nélküli szakaszban történik a mély alvás, különösen a 3. fázisban, amelyet lassú hullámú alvásnak is neveznek (slow-wave sleep; SWS) $(4,11)$.
Az alvás-ébrenlét ciklust részben a cirkadián ritmus, részben pedig homeosztatikus folyamatok irányítják (4, 10). Az alvás e két tényező eredőjeként jön létre: előbbi időzíti az alvást, az utóbbi pedig annak mélységét határozza meg. A cirkadián ritmus hangolja össze az alvási ciklust a napszakokkal: napközben gátolja, éjszaka pedig elösegíti az alvás megjelenését (11).

A nyugati világra jellemző kulturális és környezeti hatások megzavarhatják a cirkadián ritmust. Az ember akaratilag is felülírhatja a viselkedésével, életmódjával az alvásszabályozás feletti természetes fiziológiai kontrollt. Így például az elnyújtott munkaórák, műszakos munkarend, jetlag, extenzív kávéfogyasztás, rendszertelen étkezés, a nagyvárosokra jellemző fény- és zajszenynyezés, elektronikus eszközök használata mind-mind a cirkadián ritmus zavarához vezethetnek $(4,5,9,11)$.

$\mathrm{Az}$ energiaháztartásban szerepet játszó hormonok koncentrációja is váltakozik a cirkadián ritmus során. A szervezet energiaháztartásában kulcsfontosságú szerepet játszó inzulin hyperglykaemia hatására választódik ki, és gátolja a cirkadián ritmust azzal, hogy este több termelödik belöle, mint reggel. A szövetek metabolizmusát is befolyásolja a cirkadián ritmus: éjszaka alacsonyabb a szövetek inzulinrezisztenciája, tehát ilyenkor magasabb a glükóz koncentrációja. A napi biológiai óra megzavarása tehát a metabolizmus zavarához vezethet (11). A rendszertelen alvás és táplálkozás pedig elhízást okoz. Mindkettő szerepet játszik a 2-es típusú diabétesz és a kardiovaszkuláris betegségek kialakulásában $(13,14)$.

\section{Kutatási eredmények}

A 2-es típusú diabétesz és az elhízás elterjedésével párhuzamosan a modern társadalmakban lecsökkent az emberek alvással eltöltött ideje. Epidemiológiai tanulmányok szerint a rövid, fragmentált, nem megfelelő minőségủ vagy rosszul időzített alvás megnöveli a metabolikus zavar kialakulásának kockázatát $(5,13)$.

Az obstruktív alvási apnoe szindróma (obstructive sleep apnea; OSA) egy légzéskimaradással járó alvászavar, amelyre jellemző a hypoxia, fragmentált alvás, kevés lassú hullámú alvási ciklusban eltöltött idő és az öszsz-alvásidő lecsökkenése (10). Az OSA az 50 év feletti férfiak $17 \%$-ánál, és az 50 év feletti nők $9 \%$-ánál fordul elő, és gyakoribb a túlsúlyos személyeknél. Ez a fajta alvászavar bizonyított rizikófaktora az inzulinrezisztenciának és a 2-es típusú diabétesznek $(5,8,11)$.

Laboratóriumi alvásmegvonásos vizsgálatok azt mutatták ki, hogy az alvás megzavarása, és a csökkent alvásmennyiség glükóz-intoleranciát és inzulinrezisztenciát eredményez, ezáltal növeli a 2-es típusú diabétesz kialakulásának kockázatát $(4,9,13)$. Hasonló eredményre jutott az a vizsgálat, amely a cirkadián ritmustól eltérő időben történő alvás hatását vizsgálta. Éjszakai műszakos nővérekkel végzett longitudinális kí- 
sérlet eredménye szerint az éjszakai munka megnöveli a súlygyarapodást és a 2-es típusú diabétesz kialakulását eredményezheti (14).

Tasali, Leproult, Ehrmann és Van Cauter (15) azt a hipotézisüket tesztelték, hogy az SWS-ciklusban megzavart alvás befolyásolja-e a glükóz-metabolizmust. Öszszefüggést találtak a kevesebb SWS-fázisban eltöltött idő és a csökkent inzulinérzékenység között, amely nem kompenzálódott emelkedett inzulinfelszabadulással. Ez a jelenség magyarázatul szolgálhat, hogy a rossz alvásminőség miért növeli 2-es típusú diabétesz kialakulásának kockázatát (15). Mivel az obstruktív alvási apnoés betegekre jellemző, hogy kevesebb időt töltenek az SWS-fázisban, lehet, hogy ez a mechanizmus áll a mögött, hogy a szindrómában szenvedők között több a cukorbeteg (11). Egy 2013-ban végzett kutatás, a vizsgálatban részt vevők éjszakai alvását SWS- és REM-fázis alatt is megzavarták. Eredményeik alapján arra jutottak, hogy a különböző ciklusok közül az SWS játszik kulcsszerepet a glükózmetabolizmus szabályozásában (9). Idősebb korban megváltozik az alvás szerkezete. A kor előrehaladtával mind az SWS- mind a REM-fázisban eltöltött idő lecsökken az össz-alvásidőhöz viszonyítva. Lehetséges, hogy ez a magyarázata annak, hogy idősebb korban gyakoribb a metabolikus szindróma előfordulása (13).

Cappuccio, D'Elia, Strazzullo és Miller (16) 10 publikáció alapján végeztek meta-analízist. Szignifikáns öszszefüggést találtak az alvási idő és a 2-es típusú diabétesz kialakulása között. $A$ vizsgálatokban résztvevők közül azok között, akik átlagosan 5-6 órát alszanak éjszakánként, $28 \%$-ánál alakult ki a betegség, és $84 \%$ nál, azok között, akiknek az alvás fenntartásában van nehézségük (16).

Knutson (2) epidemiológiai kutatásokat összefoglaló publikációjában összefüggést keresett az alvási idő/alvásminőség és az elhízás, étvágy, 2-es típusú diabétesz valamint szív- és érrendszeri megbetegedések között. Azt a következtetést vonta le, hogy kapcsolat van a rövid alvásidő, a rossz alvásminőség és a 2-es típusú diabétesz kialakulása között. Az ok-okozati viszony azonban nem egyértelmú: előfordulhat, hogy a rossz minőségű vagy kevés alvás okozza a betegség kialakulását, ugyanakkor az is elképzelhető, hogy a cukorbetegség vezet alvászavarhoz. Keresztmetszeti kutatások szerint ugyancsak nem egyértelmủ az oksági viszony a rossz alvásminőség és a kardiovaszkuláris megbetegedések valamint a magas vérnyomás között sem.

Shan és munkatársai (9) 11 prospektív kutatás metaanalízisa alapján U-alakú összefüggést találtak az alvásidő és a 2-es típusú diabétesz kialakulásának kockázata között. A kutatócsoport felhívta a figyelmet, hogy a különböző kutatások eltérnek abban, hogy mit értenek rövid és hosszú alvásidő alatt. Ezért Shan és munkatársai (9) arra törekedtek, hogy dózis-válasz függvénynyel ábrázolják az alvási idő és a 2-es típusú diabétesz kockázatának kapcsolatát. Azt a konklúziót vonták le, hogy napi 7-8 óra alvásnál a legkisebb a kockázat a cukorbetegség kialakulására.

$A z$ is előfordulhat, hogy egyéb, még diagnosztizálatlan klinikai betegség áll a hosszú alvási idő hátterében. Egy kutatás ugyanis kimutatta, hogy 2-es típusú diabéteszes betegek vizsgálata során több depresszív tünettel rendelkeztek azok a betegek, akik hosszú alvási időt jelentettek, azokkal szemben, akik 6,5-7,4 órát vallottak be (11).

A metabolikus szindróma pontos patofiziológiájának megismeréséhez és az alvászavar szerepének felfedéséhez azonban több prospektív kutatásra van szükség. A legtöbb fentebb felsorolt kutatásnak hasonló korlátaik vannak. Egyrészt a metabolikus szindróma nem egységes definíciója megnehezíti az eredmények összevethetőségét, és kutatások reprodukálhatóságát (3). Másodszor, a legtöbb vizsgálat önbevallásos módszeren alapult, így nem tudni, hogy ténylegesen mennyi időt töltöttek és milyen minőségủ alvással a vizsgálatban részt vevők. Az objektív mérőeszközök alkalmazása azonban jelentősen megnöveli a kutatás költségeit (2, $5,9)$. Manapság nagyon népszerủek az okos órák, és a nyugati társadalmakban igencsak elterjedtek. Megoldás lehetne esetleg, ha ezeket az eszközöket használnák fel az alvás adatainak rögzítéséhez. Harmadrészt, nem lehet kizárni a diagnosztizálatlan betegségeket, amelyek szintén befolyásolhatják az alvás minőséget (11). Negyedrészt fontos szem előtt tartani, hogy nagyon soktényezős folyamatról van szó, és nehéz olyan statisztikai modellt alkalmazni, ami az összes változóval számol (9). Továbbá a vizsgálatokból legfeljebb korrelációt tudnak feltételezni, az oksági viszony továbbra is kérdéses. Valószínüsíthető, hogy kétirányú kapcsolat van a metabolikus szindróma és pszichoszociális tényezők között $(2,5)$.

\section{A lehetséges mechanizmusok az alvászavar és metabolikus szindróma közőttt}

Egyelöre nem ismert, hogy milyen oksági kapcsolat van az alvászavar és a 2-es típusú diabétesz valamint a metabolikus szindróma között, valamint a háttérben álló pontos patofiziológia sem feltárt még teljes mértékben $(9,11)$. Valószínúleg nem egyetlen mechanizmus a felelös, hanem több molekuláris folyamat együttesen járul hozzá a cukorbetegség és a kardiovaszkuláris megbetegedések kialakulásához $(2,5)$.

A modern társadalmak nagyvárosaira jellemző állandó fényszennyezés miatt változás állhat be a melatonin termelődésében. Mivel a melatonin mediátor szerepet játszik a központi és a perifériás cirkadián óra között, a változás a cirkadián ritmus eltolódásához vezet, amely metabolizmus zavart okozhat (11). Shan és munkatársai (9) a melatonin mellett megemlítik a tesztoszteron szerepét is, amelyre szintén csökkent szekréció jellem- 
ző az éjszaka folyamán. A tesztoszteron szekrécióját is befolyásolhatja az alvásmegvonás vagy a fragmentált alvás. Ez a reakcióút szintén hozzájárulhat a cukorbetegség kialakulásához.

Az elégtelen alvás miatt változás következik be az evési hormonok szintjében is. Számos kutatás azt figyelte meg, hogy alvásmegvonás esetén csökken a leptinszint, a ghreliné pedig növekszik, amely fokozza az étvágyat. Más kutatások azonban nem találtak ilyen jellegü változást $(10,13)$.

Az alvás megzavarása, a cirkadián ritmus eltolódása étvágy fokozódásához vezet $(4,9,11,14)$. Alvásmegvonásos vizsgálatok, és müszakban dolgozókkal végzett kutatások azt figyelték meg, hogy több, és magasabb kalóriatartalmú ételt fogyasztanak, mint az optimális alvás esetén. Azt várnánk, hogy a hosszabb ébrenlét fokozza az energiafelhasználást, de kutatások szerint mégis az látszik, hogy a megnövekedett éhség, és az emiatt bekövetkező többletkalória-bevitel jóval több, mint amennyi energiát a hosszabb ébrenlét alatt fel tudunk használni. Mi több, a fáradtság miatt kevesebb fizikai aktivitást végeznek. Ezek a hatások pedig növelik az elhízás kockázatát $(5,11,14)$. Az elhízás pedig már ismert rizikófaktora a diabétesznek és kardiovaszkuláris megbetegedéseknek (2).

Az elégtelen alvás a szimpatikus idegrendszer aktivitásának fokozásán keresztül is vezethet a metabolikus szindróma kialakulásához azáltal, hogy csökkenti a $\beta$-sejtek válaszreakcióját és gátolja az inzulinszekréciót, valamint fokozza a lipolízist és megnöveli a szabad zsírsav-koncentrációt. Ezek a hatások pedig inzulinrezisztenciát okozhatnak $(2,9,11)$. A szimpatikus idegrendszer aktivitásának emelkedése vérnyomás-emelkedéshez vezet, amely hosszú távon tartós hipertenziót okoz, ami növeli a szív- és érrendszeri megbetegedések kialakulásának kockázatát (2). Egyes kutatások azt találták, hogy a noradrenalin és adrenalin hormonok szintje megemelkedik szérumban és vizeletben alvásmegvonás után, amely hormonok szerepet játszanak a glükoneogenezis folyamatában (11).

A hypothalamus-hypophysis-mellékvese (HPA) tengely müködését és a növekedési hormonok (GH) szintjét szintén befolyásolja az alvás minősége, amelyeknek káros következményei lehetnek a glükózmetabolizmusra nézve (5). Alvásmegvonás után kortizol hormonszint növekedése figyelhető meg a nyálban a kora esti és éjszakai órákban, mikor általában a legalacsonyabb a koncentrációja normális körülmények között (11). Az emelkedett éjszakai kortizolszint csökkenti az inzulinérzékenységet másnap reggelre, és ez a változás hosszútávon csökkent glükóztoleranciához vezet (2). A növekedési hormonok szintjének emelkedése átmeneti inzulinrezisztenciát okoz az izomszövetekben, ami csökkenti ezen szövetek glükózfelvételét, és növeli a vércukorszintet. Ez a hatás pedig más szövetekben is inzulinrezisztencia kialakulásához vezet. Kutatások azt találták, hogy elégtelen alvás esetén csökken az agyi glükózfelhasználás az ébrenlét alatt, ami szintén csökkent glükóztoleranciához vezet $(2,11)$.

Az alvás nemcsak az energiaháztartás helyreállításához szükséges, hanem az immunrendszer megfelelö múködéhez is. Alvásmegvonás esetén a gyulladásos citokinek szérumszintje megnövekedik, amely hozzájárul gyulladási folyamatok kialakulásához (11).

\section{Következtetések}

A metabolikus szindróma népbetegségnek számít, ezért fontos feltárni azokat a változtatható rizikótényezőket, amellyel megelőzhető a betegség kialakulása, és személyre szabott terápiával javítható a betegek életszínvonala $(2,5)$. Cikkünkben a szintén népbetegségnek számító alvászavar metabolikus szindróma kialakulásában játszó szerepét vettük szemügyre a legfrissebb szakirodalom segítségével.

Eddigi kutatások szignifikáns összefüggést találtak a rövid alvási idő, rossz alvásminőség és a metabolikus szindróma jellemző tüneteinek megjelenése között (2, $5,7,8,9,16,17)$. A hosszú alvásidő tekintetében nem ilyen egyértelmúek a kutatási eredmények $(5,17)$.

Keresztmetszeti kutatások alapján kapcsolatot találtak a rövid és/vagy hosszú alvási idő és a túlsúly, cukorbetegség valamint magas vérnyomás megjelenése között. Longitudinális vizsgálatokból kevesebb akad a témában és az eredmények nem konzisztensek. Feltételezhető azonban, hogy az alvásidő összefügg az elhízás vagy a későbbi szív- és érrendszeri megbetegedések megjelenésével (10). Az eredmények azonban vegyesek és a fentebb említett korlátok limitálják. Ezért további longitudinális kutatásokra van szükség, ahol az alvás mérése objektív eszközökkel történik, valamint figyelembe kell venni a résztvevők korát, nemét, lakóhelyét és szocioökonómiai státuszát $(9,10,17)$.

Rangaraj és Knutson (10) áttekintőjükben azt írják, hogy párhuzamot látni manapság a modern társadalmakban az optimálistól időben és minőségben eltérő alvás és a szív- és érrendszeri megbetegedések megjelenésének növekedése között. A hipotézis igazolása még a jövő kutatóin áll. Ugyancsak érdekes lenne további vizsgálatokat látni kezelt OSA-s betegekkel. A már meglévő limitált számú kutatásból ugyanis vegyes eredmények születtek.

Az eddigi vizsgálatok eredményei alapján elmondható, hogy napi 7-8 óra alvással esetlegesen csökkenteni lehetne a metabolikus szindróma kialakulását. Ennek érdekében fontos a helyes alvási higiéné kialakítása, és szükség esetén pszicho- és/vagy farmakoterápia alkalmazása az optimális alvási idő és alvásminőség elérése érdekében $(5,9)$.

\section{Támogatás}

A kézirat az Európai Unió támogatásával, az Európai Szociális Alap társfinanszírozásával jött létre az EFOP- 


\subsection{1-16-2016-00008 projekt (Szegedi Tudományegye- tem, „Testi, lelki, és szociális egészségmegőrzés és betegségmegelőzés multidimenzionális vizsgálata, és megvalósitható egészségvédő programok kidolgozá- sa") keretében.}

\section{Irodalom}

1. Al-Qawasmeh RH, Tayyem RF. Dietary and Lifestyle Risk Factors and Metabolic Syndrome: Literature Review. Curr Res Nutr Food Sc 2018; 6(3): 594-608. doi:http://dx.doi.org/10.12944/CRNFSJ.6.3.03 2. Knutson KL. Sleep duration and cardiometabolic risk: a review of the epidemiologic evidence. Best Pract Res Clin Endocrinol Metab 2010; 24(5): 731-743. doi:10.1016/j.beem.2010.07.001

3. McCracken E, Monaghan M, Sreenivasan S. Pathophysiology of the metabolic syndrome. Clinics Dermat 2018; 36: 14-20. doi 10.1016/j.clindermatol

4. Medic G, Wille M, Hemels ME. Short and long-term health consequences of sleep disruption. Nature and Science of Sleep 2017; 9 : 151-161. doi:10.2147/NSS.S134864

5. St-Onge MP, Grandner CMA, Brown D, Conroy MB, Jean-Louis G, Coons M, et al. Sleep Duration and Quality: Impact on Lifestyle Behaviors and Cardiometabolic Health. A Scientific Statement From the American Heart Association. Circulation 2016; 134: e367-e386. doi:10.1161/CIR.0000000000000444

6. Saylor J, Friedmann E. Biopsychosocial Contributors to Metabolic Syndrome. Nurs Res 2015; 64(6): 434-443. doi: 10.1097/ NNR.0000000000000121

7. Mottillo S, Filion KB, Genest J, Joseph L, Pilote L. The Metabolic Syndrome and Cardiovascular Risk. A Systematic Review and Meta-Analysis. J Am Coll Card 2010; 56(14): 1113-1132. doi:10.1016/j. jacc.2010.05.034

8. Depner C, Stothard E, Wright K. Metabolic Consequences of
Sleep and Circadian Disorders. Curr Diab Rep 2014; 14: 507. DO 10.1007/s11892-014-0507-z

9. Shan Z, Ma H, Xie M, Yan P, Guo Y, Bao W. Sleep Duration and Risk of Type 2 Diabetes: A Meta-analysis of Prospective Studies. Diab Care 2015; 38: 529-537. https://doi.org/10.2337/dc14-2073

10. Rangaraj VR, Knutson KL. Association between sleep deficiency and cardiometabolic disease: implications for health disparities. Sleep Med 2016; 18: 19-35. https://doi.org/10.1016/j.sleep.2015.02.535 11. Reutrakul S, Van Cauter E. Interactions between sleep, circadian function, and glucose metabolism: implications for risk and severity of diabetes. Ann NY Acad Sci 2014; 1311: 151-173. DOI:10.1111/ nyas. 12355

12. Tan E, Scott EM. Circadian rhythms, insulin action, and glucose homeostasis. Curr Opin Clin Nutr Metab Care 2014; 17: 343-348. doi: 10.1097/MCO.0000000000000061

13. Cedernaes J, Schiöth HB, Benedict C. Determinants of Shortened, Disrupted and Mistimed Sleep and Associated Metabolic Health Consequences in Healthy Humans. Diab 2015; 64: 10731080. DOI: $10.2337 / \mathrm{db} 14-1475$

14. Nagy Z, Rácz K, Patócs $A$. A perifériás cirkadián órák jelentősége az anyagcserezavarok kialakulásában. Magy Belorv Arch 2014; 67: 5-11.

15. Tasali E, Leproult R, Ehrmann DA, Van Cauter E. Slow-wave sleep and the risk of type 2 diabetes in humans. PNAS 2008; 105(3): 1044-1049. doi:10.1073/pnas.0706446105.

16. Cappuccio F, D'Elia L, Strazzullo P, Miller M. Quantity and Quality of Sleep and Incidence of Type $2 \mathrm{D}$ iabetes: A systematic review and meta-analysis. Diab Care 2010; 33(2): 414-420. doi: 10.2337/ dc09-1124

17. Xi B, He D, Zhang M, Xue J, Zhou D. Short sleep duration predicts risk of metabolic syndrome: A systematic review and meta-analysis. Sleep Med Rev 2014; 18: 293-297. https://doi.org/10.1016/j. smrv.2013.06.001 